\title{
Cantharellus subg. Pseudocantharellus (Hydnaceae, Cantharellales) revisited: one epityfication, one new synonym and one new species
}

\author{
Buyck $B^{1^{*}}$ and Hofstetter $V^{2}$
}

${ }^{1}$ Muséum National d'Histoire Naturelle, Sorbonne Université, Case Postale 39, Institut Systématique, Evolution,
Biodiversité, UMR 7205 CNRS MNHN UPMC EPHE, 12 rue Buffon, F-75005 Paris, France
${ }^{2}$ Department of plant protection, Agroscope, Rte de Duiller, 1260 Nyon, Switzerland

Buyck B, Hofstetter V 2018 - Cantharellus subg. Pseudocantharellus (Hydnaceae, Cantharellales) revisited: one epityfication, one new synonym and one new species. Mycosphere 9(1), 141-148, Doi 10.5943/mycosphere/9/1/3

\begin{abstract}
Cantharellus rhodophyllus is epitypified with a recent collection from the African rain forest and full barcode ITS sequences are provided. After a detailed comparison of the original descriptions and these new collections, $C$. subincarnatus - introduced as a new name for the invalid C. incarnatus - is considered a later synonym. Phylogenetic analysis using tef- 1 sequence data place $C$. rhodophyllus in Cantharellus subg. Pseudocantharellus and demonstrate that $C$. subincarnatus subsp. rubrosalmoneus from Madagascar is an independent species that is more closely related to $C$. miniatescens.
\end{abstract}

Key words - 1 new species - Barcoding - Cantharellus rhodophyllus - Cantharellus subincarnatus - Cantharellus rubrosalmoneus - ITS - tef-1

\section{Introduction}

Mainland Africa surpasses by far all other continents with its 44 presently described endemic Cantharellus species (De Kesel et al. 2016, Buyck 2016, Buyck et al. 2017). Yet, a major priority, addressed in several recent papers (Buyck et al. 2015, Buyck et al. 2016a), remains the urgent epitypification and molecular characterization of the many African chanterelles described by Heinemann $(1958,1966)$ in view of stabilizing the earlier introduced names and corresponding species concepts. Newly sequenced specimens that were recently collected in the African rain forest, in the same habitat, and not far from where Mrs. Goossens-Fontana made the collections that were later studied by Heinemann (1.c.), are now finally available to be compared with the original material and descriptions. Thus far, recent epitypifications of Heinemann's chanterelles allowed for the redescription, correct interpretation and systematic placement of $C$. miniatescens Heinem. and C. rufopunctatus, two previously misinterpreted species (Buyck et al. 2016b, De Kesel et al. 2016), as well as for $C$. alboroseus (Buyck et al. 2016a) and some species in the $C$. congolensis-complex (Buyck et al. 2016d).

In the present contribution, the authors address the existing confusion surrounding species recognition in Cantharellus subg. Pseudocantharellus with the epitypification of C. rhodophyllus Heinem. This epitypification additionally results in the recognition of a new synonym and a new species. 


\section{Material and Methods}

Morphology. - Color notations follow Kornerup \& Wanscher (1978). Microscopic features were examined and sketched with the aid of a camera lucida. Original drawings for all elements of the hymenium or pellis were made at a magnification of $2400 \times$. All microscopic observations and measurements were made in ammoniacal Congo red after a short pretreatment in a $10 \%$ aqueous $\mathrm{KOH}$ solution to improve tissue dissociation and matrix dissolution. Measurements of basidiospores cite length, width and length/ width ratio $(\mathrm{Q})$ in this format: (minimum-) mean minus standard deviation - mean value - mean plus standard deviation ( - maximum measured); spore measurements are based on 20 spores.

Taxon sampling and Phylogenetic analyses. - Genomic DNA isolation, amplification and sequencing of the transcription elongation factor 1-alpha (Tef-1) for the here newly analyzed Cantharellus collections were performed as described in Buyck et al. (2014) including some Tef-1 sequences from previous publications (Buyck et al. 2016b) and using Craterellus tubaeformis as the outgroup.

The Tef- 1 alignment included 92 specimens and was performed by eye in MacClade 4.05 (Maddison \& Maddison 2002). The alignment used for phylogenetic analyses included 629 characters after exclusion of three spliceosomal introns (full alignment length: $864 \mathrm{bp}$ ). Searches for optimal tree and branch robustness were conducted with the program PhyML (Guindon \& Gascuel 2003), with the search starting from a distance-based tree and with the proportion of invariable sites, the gamma shape parameter and the number of substitution categories estimated during the search. Three independant runs were conducted to check for convergence to the same

likelihood value. Branch support was estimated based on 500 bootstrap replicates (ML-bs) and was considered significant when $\geq 70 \%$ (Alfaro et al. 2003)

\section{Results}

\section{Phylogenetic results}

The tree independent RAxML runs to search for the most likely tree exhibited nearly identical topologies and the one that maximizes the likelihood value $(-\ln =5713.37719)$ is depicted in Fig.1. Phylogenetic analyses (Fig. 1) place C. rhodophyllus (ML-bs $=100 \%$ ) monophyletic (MLbs $=87 \%$ ) and sister (ML-bs $=77 \%)$ to a monophyletic group constituted by $C$. miniatescens and C. rubrosalmoneus sp. nov. (ML-bs $=100 \%$ ). This clade corresponds to Cantharellus subg. Pseudocantharellus in Buyck et al. (2014). Identical barcode ITS sequences (1137 base pairs) were obtained for both our collections from the Central African Republic; these have been deposited in GenBank as barcode reference sequences (C. rhodophyllus 1638/BB16.006/PC 0142499, accession number MG450680; C. rhodophyllus 1678/BB 16.126/PC 0142500, accession number MG450681).

\section{Taxonomy}

Cantharellus rhodophyllus Heinem., Bulletin du Jardin Botanique de l'État à Bruxelles 28: 404. 1958.

= Cantharellus subincarnatus Eyssartier \& Buyck, Doc. Mycol. 31 (121): 55 (2001), syn. nov

= Cantharellus incarnatus Heinemann, Bull. jard. bot. État Brux. 28: 402 (1958), nom. inval.

= Lentinus incarnatus Beeli, Bull. Soc. Roy. Bot. Belg. LX: 161, pl. IV, Fig. 24 (1928), basionym

Holotype: DEMOCRATIC REPUBLIC OF THE CONGO. Binga, on the soil in Gilbertiodendron dewevrei forest, July 1931, Miss Goossens-Fontana 937 (BR).

Iconography: Heinemann 1958, Fig. 41; 1959, pl. XXVII, Fig. 1a.

Diagnosis and original description (freely translated from French):

Pileus carnosus, centro depressus, lobatus, armeniacus, furfuraceo-hirsutus. Stipes validus, armeniaco-luteus, mycelio aureo praeditus. Lamellae angustae, confertiusculae, roseae, fragiles, furcatae et anastomosatae. Caro aquosa, crocea-luteola. Sporae 7-9 x 5,3-5,7 $\mu \mathrm{m}$, ellipticae. 


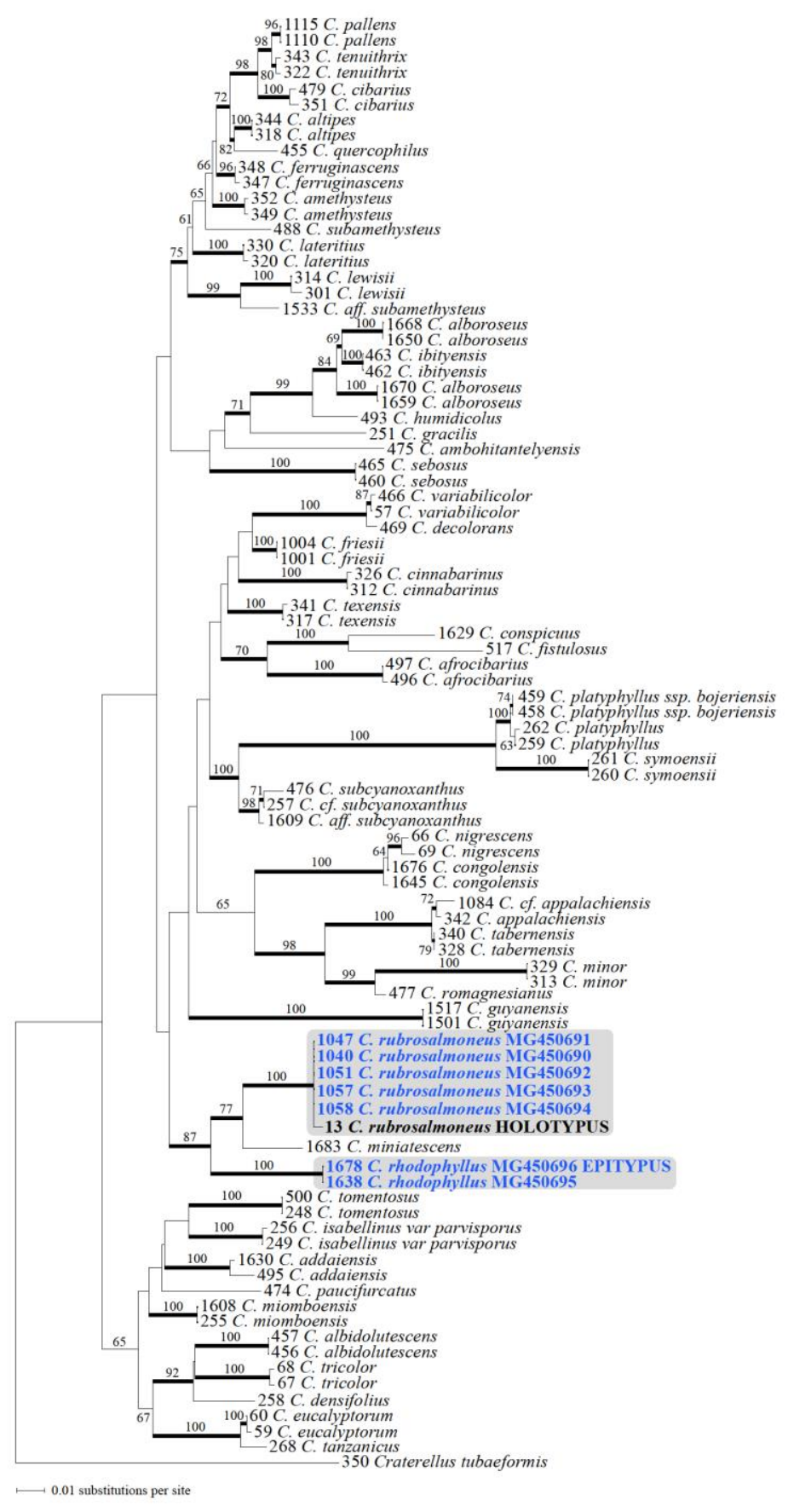

Figure 1 - Most likely tree obtained by analyses of 92 Tef-1 sequences sampled from Buyck et al. (2016b). Branches significantly supported are in bold and bootstrap values are indicated along the branches. Newly produced sequences are highlighted in blue with taxon names followed by GenBank accession numbers.

Pileus ca. $12 \mathrm{~cm}$ diam., thick and fleshy, depressed in the center, with convex, irregularly lobed or undulating margin; surface a dark orange-pink, furfuraceous to even hirsute from small, fibrillose, vertically dressed and more or less detersile squamulae. Stipe ca. 13 x $2 \mathrm{~cm}$, vigorous, irregularly cylindrical, tomentose (?), with shades of pinkish orange and bright yellow, not hollowing; mycelium bright ochre, visible at the base. Lamellae narrow, up to $4 \mathrm{~mm}$ high, rather densely spaced, thick and brittle, narrowing at the extremities, deeply decurrrent, pinkish, unequal, forked, at their bases veined-anastomosing. Context watery, strongly fibrous, safran yellow especially in the stipe; when boiling a fragment of the exsiccatum releasing a weak odor of $C$. 
cibarius. Exsiccatum: entirely reddish brown, basal mycelium bright red; with abundant, bluish to white punctate efflorescences on the entire surface.

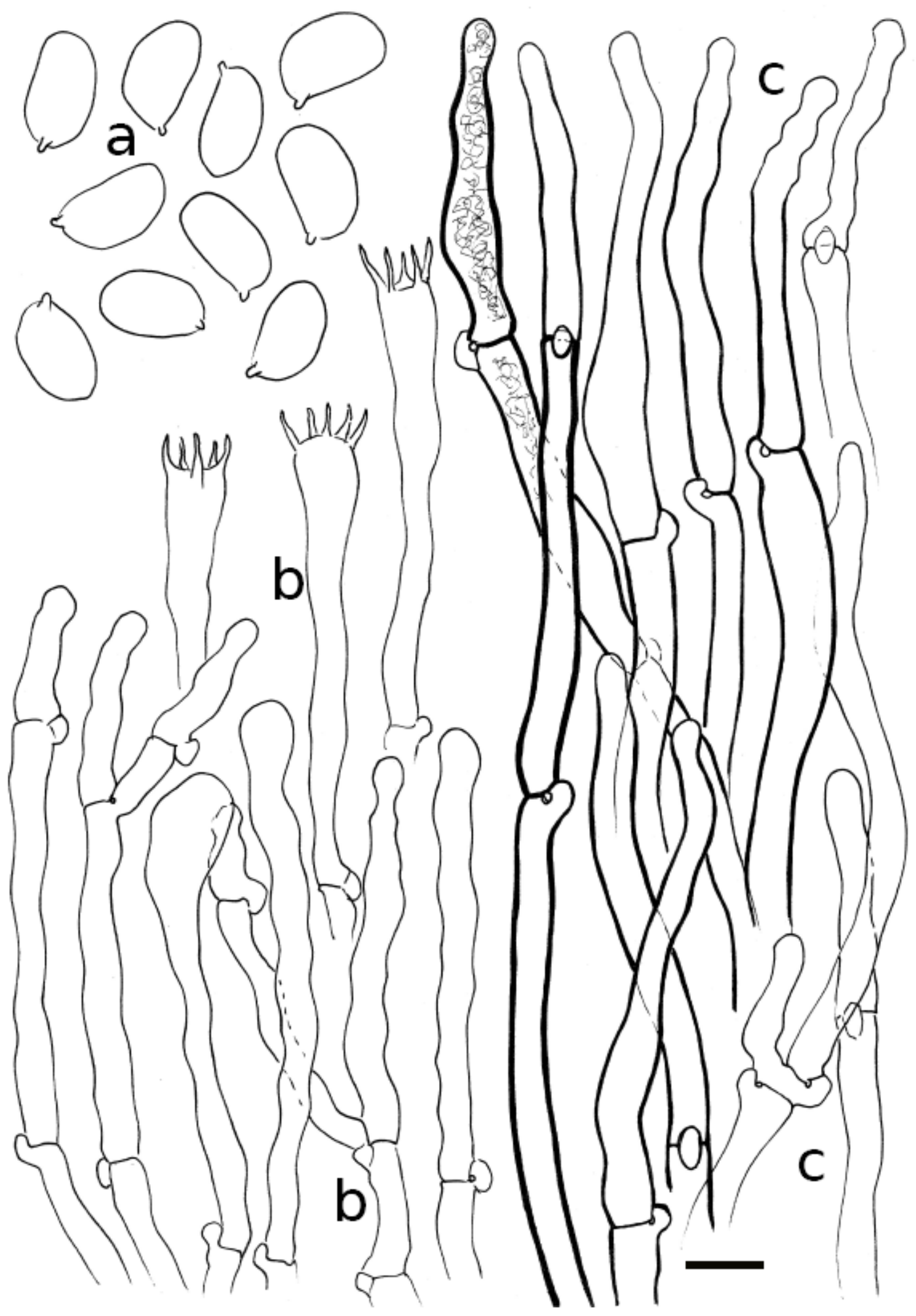

Figure 2 - Cantharellus rhodophyllus (epitype BB16.126). a Spores. b Basidia and basidiola. c Hyphal terminations in the pileipellis. Scale $=10 \mu \mathrm{m}$, but only $5 \mu \mathrm{m}$ for spores. 
Spores 7-9 x 5.3-5.7 $\mu \mathrm{m}$, ellipsoid, sometimes slightly depressed in the middle, thin-walled, with a small apiculus. Basidia $45-60 \times 6.5 \mu \mathrm{m}$ for example (n ${ }^{\circ} 833$ bis). Pileipellis with squamules formed of fasciculated yellowish hyphae with clamp connections, 4-10 $\mu \mathrm{m}$ diam., thick-walled,with terminal elements narrowly lanceolate to cylindrical with obtuse tips. Pseudoparenchyma very compact, lacunar.

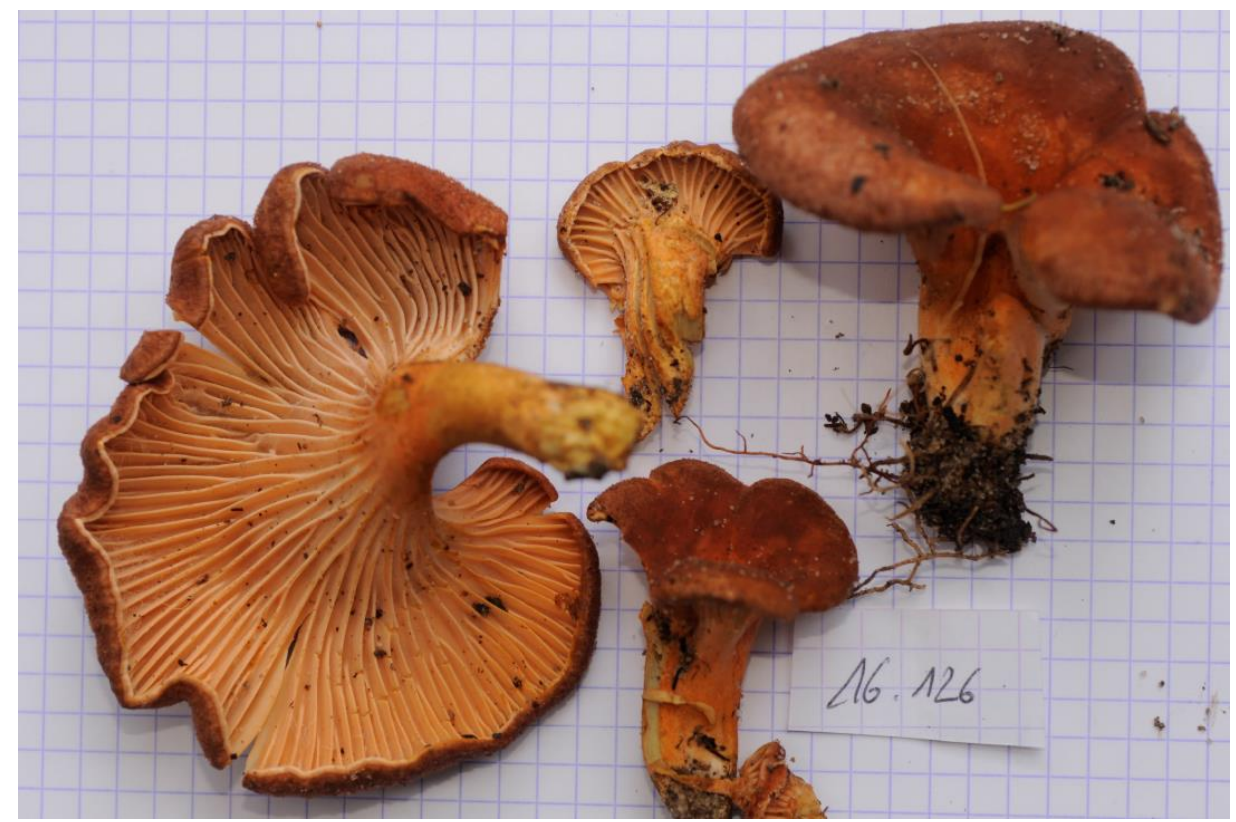

Figure 3 - Cantharellus rhodophyllus (epitype BB16.126). Habit when fresh. Scale: one rectangle side on the paper equals $0.5 \mathrm{~mm}$. Photo: B. Buyck.

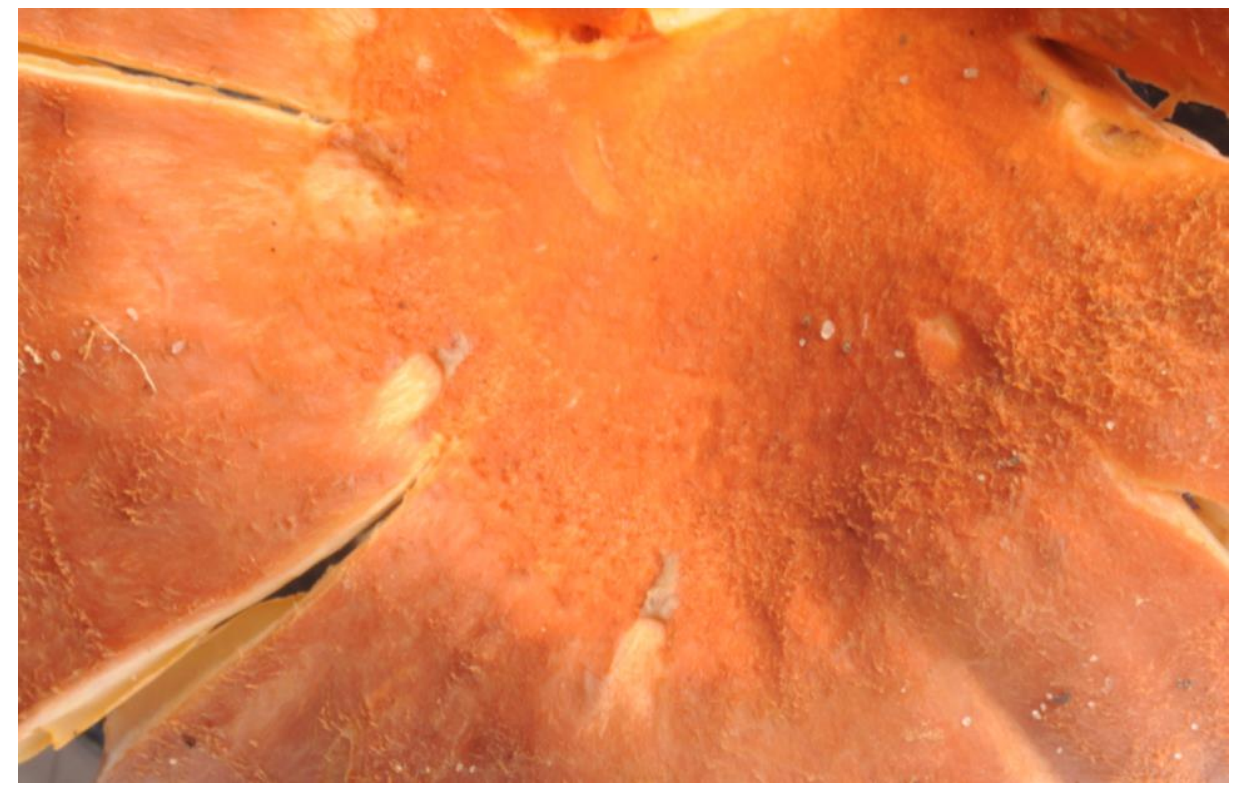

Figure 4 - Cantharellus rhodophyllus (epitype BB16.126). Detail of the scurfy-fibrillose cap surface. Photo: B. Buyck.

\section{Epitype description}

Basidiomata dispersed, fleshy and firm, up to $70 \mathrm{~mm}$ high. Pileus entirely hairy-fibrillose and covered by distinct trichoid elements vertically dressed particularly toward the margin, brownish orange $(7 \mathrm{BC} 7-8,7 \mathrm{C} 6)$ in the center, deepening to brown or reddish brown elsewhere (7DE7-8, 8DE7). Hymenophore decurrent, composed of well-differentiated gill folds, up to $4 \mathrm{~mm}$ high, 
unequal and near the cap margin spaced ca $1 / \mathrm{mm}$, only rarely forking, not interveined, not abruptly delimited from the sterile stipe surface, very pale when young but then turning into a beautiful salmon color (6A5-7). Stipe subcylindrical, slightly narrowing downward, (25)40-45 x (6)10-22 $\mathrm{mm}$, tinged with pink to salmon patches (7A5-77-8, 7B), massive and firm. Context firm and thick, sometimes appearing 'layered' in the upper stipe, strongly yellowing (also visible on the outer surface), particularly in the stipe lower halve and there even turning ferruginous. Smell strong and typical. Taste mild. Spore print whitish.

Spores ellipsoid, (6.4)6.8-7.25-7.6(8.1) x (3.9)4.0-4.34-4.6(5.2) $\mu \mathrm{m}, \mathrm{Q}=(1.4) 1.6-1.67-1.8$, smooth, with small apiculus. Basidia 51-60(76) x 7-8 $\mu \mathrm{m}$, clavulate, predominantly 5-spored; sterigmata rather slender, 5-7 $\mu \mathrm{m}$ long; basidiola long and slender, cylindrical, then finally apically swollen. Subhymenium filamentous, composed of long, slender, cylindrical cells. Pileipellis composed of long and slender, multi-celled hyphal extremities, adhering together in long tufts or trichoids, 4-6(8) $\mu \mathrm{m}$ diam., with relatively spaced septa and slightly thickened walls (only rarely up to $1 \mu \mathrm{m}$ thick), rapidly disintegrating in smaller units when making microscopic preparations; the terminal cell generally narrowing upward and often subcapitulate or repeatedly slightly constricted at the apex, (20)35-65(90) $\mu \mathrm{m}$ long, often with rather granular, not crystalline pigment inclusions. Clamp connections rather small and everywhere.

Examined and sequenced material: Central African Republic. Dzanga-Sangha Forest Reserve, near Bayanga, close to Bai-Hakou base camp, N 02.859934- E 16.467492, under monospecific Gilbertiodendron dewevrei forest, on bare sandy soil, 21 May 2016, Buyck 1638/BB 16.006 (PC 0142499); ibid., 26 May 2017, Buyck 1678/BB 16.126 (PC 0142500, epitypus hic designatus).

Commentary: This species has been collected by Mrs Goossens-Fontana almost a century ago in the area of Binga, some $400 \mathrm{~km}$ across the border from where our specimens were gathered. Heinemann's description does not discuss the evident similarities shared between $C$. rhodophyllus and $C$. subincarnatus Eyssart. \& Buyck (ut $C$. incarnatus Heinemann, nom. inval.), both of which are illustrated side by side (Heinemann 1959, Figs 1, 2). The Latin epithet of each species could equally apply to the other one as both were described with similar colors for cap, stipe and gills and both share a yellowing context. Moreover, both descriptions mention a cap surface covered with concolorous squamules and mention similar diameters for hyphal extremities on the cap surface; both descriptions also suggest a similar length-width ratio for spores although spore size is slightly different. Indeed, the spore size of $C$. rhodophyllus was described as $7-9$ x $5.3-5.7 \mu \mathrm{m}$ versus $6.9-7.8 \times 4.3-4.8 \mu \mathrm{m}$ for $C$. subincarnatus (Table 2). Notwithstanding the considerably wider spores of $C$. rhodophyllus, spores were illustrated (Heinemann 1958) exactly in the opposite way, viz. with the broadest spores for $C$. subincarnatus. The approximate length-width ratio (Q) for spores based on median values (in the absence of mean values) results in 1.45 versus 1.54 for $C$. subincarnatus, and this without accounting for Heinemann's mention of the occurrence of spores up to $11 \mu \mathrm{m}$ long in $C$. subincarnatus which would raise $\mathrm{Q}$ values $>2$ ). While Eyi Ndong et al. (2011) considered $C$. rhodophyllus as the species having the most elongate spores, the reexamination of both holotypes by Eyssartier (2001) suggested that Heinemann's measurements for $C$. rhodophyllus were most likely erroneous as Eyssartier measured near identical spore sizes for both holotypes and these correspond extremely well to spore measurements of our recently collected specimens (Table 1). Heinemann (1958) mentioned thick-walled hyphae in the pileipellis of $C$. rhodophyllus but he did not specify wall thickness for hyphal extremities in C. subincarnatus and illustrated both species as having thin-walled elements. Eyssartier (2001) noted for both type specimens similar, (very) faintly thickened cell walls $(<0.5 \mu \mathrm{m})$. This corresponds quite well with our specimens and also agrees more with Heinemann's illustrations rather than with his descriptions. When considering the general field habit, clear distinctions between both descriptions are again difficult to find as the watercolors published by Heinemann (1959) depict for each species both a more slender, pale specimen as well as a more robust, darker specimen. Our specimens correspond very well to fig. $2 \mathrm{~b}$ for $C$. subincarnatus in Heinemann (1959, ut $C$. incarnatus) and they clearly also resemble the specimens identified as such by Eyi Ndong et al. (2011), but they 
share the yellowish stipe of the more robust $C$. rhodophyllus illustrated in Heinemann (1959: see his Fig. 1a).

In conclusion, we fail to find any significant differences between both type specimens and therefore conclude that they represent a single species as already suggested by both Eyssartier (2001) and De Kesel et al. (2016). The nomenclatural priority to name this species goes to $C$. rhodophyllus, thereby assigning the replacement name $C$. subincarnatus for $C$. incarnatus nom. inval. as a later synomym.

Cantharellus rhodophyllus may exhibit a context zonation similar as the one reported for $C$. coccolobae in subg. Cinnabarinus (see Buyck et al. 2016c). This occasional phenomenon concerns either whole fructifications or individual fruiting bodies and appears to have no particular taxonomic significance.

Table 1 Comparison of obtained spore measurements for both species.

\begin{tabular}{|c|c|c|}
\hline \multicolumn{3}{|l|}{ Cantharellus rhodophyllus } \\
\hline Heinemann (1958) & $7-9 \times 5.3-5.7$ & Not given \\
\hline Eyi Ndong et al. (2011) & $(6.7) 6.8-7.9-8.8 \times(4.9) 4.7-5.5-6.2(6.5)$ & $\mathrm{Q}=(1.17) 1.21-1.43-1.65(1.68)$ \\
\hline Eyssartier (2001 holotype) & $6.5-7.39-9 \times 3.5-4.21-5$ & $\mathrm{Q}=1.62-1.76-1.87$ \\
\hline 1678/BB16.126 = Epitypus & $(6.4) 6.8-7.25-7.6(8.1) \times(3.9) 4.0-4.34-4.6(5.2)$ & $\mathrm{Q}=(1.4) 1.6-1.67-1.8$ \\
\hline 1638/BB16.006 & $(6.4) 6.7-7.10-7.5(7.9) \times(3.9) 4.0-4.28-4.5(4.8)$ & $\mathrm{Q}=(1.4) 1.5-1.67-1.8(2.0)$ \\
\hline \multicolumn{3}{|l|}{ Cantharellus subincarnatus } \\
\hline Heinemann (1958) & $6.9-7.8 \times 4.3-4.8$ & Not given \\
\hline Eyi Ndong et al. (2011) & $(6.9) 7.0-7.7-8.4(8.8) \times(4.1) 4.2-4.6-5.1(5.3)$ & $\mathrm{Q}=1.47-1.66-1.85(1.90)$ \\
\hline Eyssartier (2001 holotype) & $6-7.5-9 \times 4-4.5-5$ & $\mathrm{Q}=1.4-1.66-2$ \\
\hline
\end{tabular}

Cantharellus rubrosalmoneus (Buyck \& V. Hofst.) Buyck \& V. Hofst., comb. et stat. nov.

Basionym: Cantharellus subincarnatus subsp. rubrosalmoneus Buyck \& V. Hofst., Fungal Diversity 70:203 (2015)

Additional examined and sequenced material: MADAGASCAR. East coast, Tamatave prov., at Ambila Lemaitso, in sandy soil under Asteropeia multiflora, Sarcolaena spp., Leptolaena spp., Uapaca littoralis, S18.87713-E049.13429, 27 June 2011, 1040/Buyck 11.038 (PC 0085571), ibid., 1047/Buyck 11.052 (PC 0085578), Tampolo forest station, in sandy soil of littoral forest with Uapaca and Sarcolaena spp., S17.28719-E049.41478, 3 July 2011,1051/Buyck 11.087 (PC 0085582), ibid., S17.28454-E049.42875, 6 July 2011, 1057/ Buyck 11.133 (PC 0085588), ibid., S17.28719-E049.41478, 8 July 2011, 1058/ Buyck 11.166 (PC 0713950).

Commentary: More recently, Buyck et al. (2015) described from Madagascar's east coast also a $C$. subincarnatus subsp. rubrosalmoneus Buyck \& V. Hofst., which clearly constitutes an independent though closely related species in our phylogenetic analyses (Fig. 1) and is sister with significant support to $C$. miniatescens $(\mathrm{ML}$ bs $=77 \%$ ). Consequently, we raise it here to species level.

This Malagasy species is easily distinguished from C. rhodophyllus because of its more reddish orange color, different cap surface texture and the much denser, less well-developed and often strongly anastomosing gill folds. It resembles more the probably closely related $C$. ruber Heinem. described from African woodland (Heinemann 1966).

\section{Acknowledgements}

The first author thanks the ATM program of the Paris' Museum and 'l'Institut Ecologie et Environnement" (CNRS-INEE) for funding the field trip with Shelly Masi to Africa; Shelly is thanked for all the practical help and sharing her experience. Terence Fuh and the staff of the Primate Habituation Program of the Dzanga-Ndoki National Park of the "Reserve speciale de Foret Dense de Dzanga-Sangha at Bayanga, as well as all staff, Aka guides and visitors of the Bai hakou field station for logistical support, field assistance and the very enjoyable company during our stay. This research was made possible through research permit 
034/MENESR/DIRCAB/DGESRSTI/DRSTSPI/SSSTI/16 from the "Ministère de l'éducation nationale, de l'enseignement supérieur et de la recherche scientifique" of the Central African Republic.

\section{References}

Alfaro M, Zoller S, Lutzoni F. 2003 - Bayes or bootstrap? A simulation study comparing the performance of Bayesian Markov chain Monte Carlo sampling and bootstrapping inassessing phylogenetic confidence. Molecular Biology and Evolution 20: 255-266.

Buyck B. 2016 - Editorial Special Issue: Cantharellus. Towards completing the world inventory of Cantharellus. Cryptogamie Mycologie 37: 255-258

Buyck B, De Crop E, Verbeken A, Hofstetter V. 2016a - Untangling the Central African Cantharellus sect. Tenues: Cantharellus minutissimus sp.nov. and epitypification of Cantharellus alboroseus. Cryptogamie Mycologie 37: 329-344.

Buyck B, Duhem B, Das K, Jayawardena RS et al. 2017 - Fungal Biodiversity Profiles 21-30. Cryptogamie Mycologie 38:101-146

Buyck B, Henkel TW, Dentinger BTM, Séné O, Hofstetter V. 2016b - Multigene sequencing provides a suitable epitype, barcode sequences and a precise systematic position for the enigmatic African Cantharellus miniatescens. Cryptogamie Mycologie 37: 269-282.

Buyck B, Kauff F, Eyssartier G, Couloux A, Hofstetter V. 2014 - A multigene world phylogeny for Cantharellus. Fungal Diversity 64: 101-121.

Buyck B. Kauff F, Randrianjohany E, Hofstetter V. 2015 - Sequence data reveal a high diversity of endemic Cantharellus associated with native vegetation in Madagascar. Fungal Diversity 70: 189-208.

Buyck B, Moreau P-A, Courtecuisse R, Kong A et al. 2016c - Cantharellus coccolobae sp. nov. and Cantharellus garnieri, two tropical members of Cantharellus subg. Cinnabarinus. Cryptogamie Mycologie 37: 391-404

Buyck B, Randrianjohany E, Hofstetter V. 2016d - Almost one century later Cantharellus avellaneus finally rediscovered! Cryptogamie Mycologie 37: 259-268.

De Kesel A, Amalfi M, Kasongo B, Yorou NS et al. 2016 - New and interesting Cantharellus from tropical Africa. Cryptogamie Mycologie 37: 283-327.

Eyi Ndong HE, Degreef J, De Kesel A. 2011 - Champignons comestibles des forêts denses d'Afrique Centrale. Taxonomie et identification. ABC Taxa 10, 253 pp. Brussels.

Eyssartier G. 2001 - Vers une monographie du genre Cantharellus Adans.:Fr. 259 p. Dissertation, National History Museum, Paris.

Guindon S, Gascuel O. 2003 - A simple, fast, and accurate algorithm to estimate large phylogenies by maximum likelihood. Systematic Biology 52: 696-704.

Heinemann P. 1958 - Champignons récoltés au Congo Belge par Madame Gossens-Fontana. III. Cantharellineae. Bulletin du jardin botanique de l'État Bruxelles 28: 385-438.

Heinemann P. 1959 - Cantharellineae. Flore iconographique des champignons du Congo 8: 153165, pl. 26-28.

Heinemann P. 1966 - Cantharellineae du Katanga. Bulletin du Jardin Botanique de l'État Bruxelles 36: $365-352$.

Kornerup A, Wanscher JH. 1978 - Methuen handbook of colour. 3rd ed. London: Methuen \& Co. Ltd. 252 pp, 30 pl.

Maddison DR, Maddison WP. 2002 - MacClade: Analysis of Phylogeny and Character Evolution, version 4.05. Sinauer Associates Inc., Sunderland, Massachusetts, USA 